\section{Journal of Vasculare Research}

\section{KARGER}

(C) 2003 S. Karger AG, Basel

Fax +41613061234

E-Mailkarger@karger.ch

www.karger.com

Accessible online at: www. karger.com/jvr

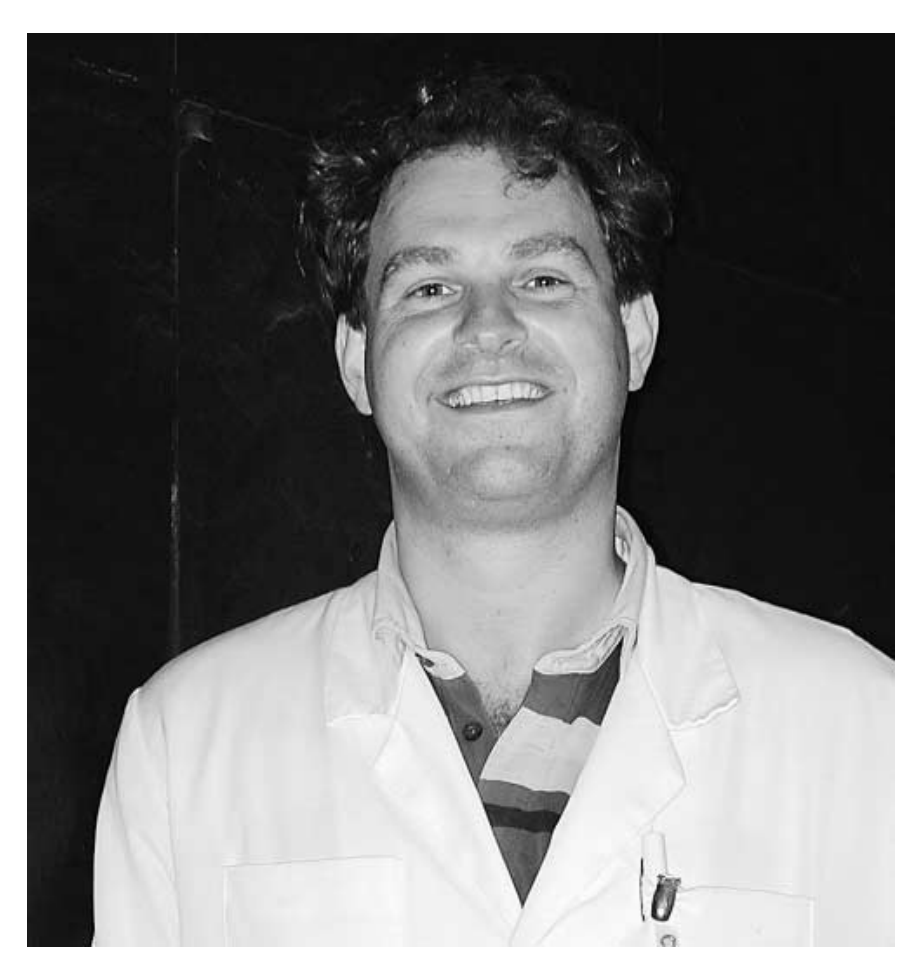

\section{Hermann Rein Award 2003}

The Hermann Rein Award 2003 of the German Society for Microcirculation and Vascular Biology (Gesellschaft für Mikrozirkulation und Vaskuläre Biologie e.V.), amounting to EUR 2,000 and sponsored by SERVIER Deutschland GmbH, was granted to Dr. Christopher Heeschen (Molecular Cardiology, University of Frankfurt) in recognition of his paper:

Heeschen C, Aicher A, Lehmann R, Fichtlscherer S, Vasa M, Urbich C, Mildner-Rihm C, Martin H, Zeiher AM, Dimmeler S: Erythropoietin is a potent physiologic stimulus for endothelial progenitor cell mobilization. Blood 2003;102:1340-1346. 